\title{
Effect of entomopathogenic fungi of the genus Lecanicillium on behavioral reactions and average per-day fecundity of the predatory bug Orius laevigatus Fieber (Heteroptera, Anthocoridae)
}

\author{
Irina Pazyuk* , Anna Choglokova, and Galina Mitina \\ FSBSI VIZR All-Russian Institute of Plant Protection, 196608, 3 Podbelskogo, Pushkin, \\ St. Petersburg, Russian Federation
}

\begin{abstract}
The results of studying the effect of spores and mycelium of entomopathogenic fungi of the genus Lecanicillium on the behavioral responses of predatory bugs Orius laevigatus and their fecundity are provided. In a laboratory experiment, the location of the bug adults was assessed after 24 hours, as well as the average daily fecundity of females with a free choice between a bean leaf with agar (control) and a bean leaf with sporulating fungal mycelium (experiment). It was found that the neutral reaction prevailed in the behavior of the bugs. The repellent reaction of predators was caused by the mycelium of three strains: V1 29 (L. lecanii), ARSEF 2332 (L. dimorphum), Vit 71 (L. attenuatum); the index of aggregation ranged from -40.7 to $-50(\mathrm{P}<0.05)$. Strain Vl 5 (L. lecanii), index of aggregation +43.3 , caused a significant attractive reaction. The strains causing a repellant reaction of bugs did not affect the average per-day fecundity of females. Only two strains V1 72 of L. muscarium and V1 79 of L. dimorphum caused a significant decrease in the fecundity of O. laevigatus, while the reaction of bugs to the mycelium of these strains was neutral. In the absence of a negative effect of fungi on the fecundity of bugs, the combined use of these biological agents may be promising.
\end{abstract}

\section{Introduction}

Anthocoridae bugs (Anthocoridae, Heteroptera) are an important group of beneficial insects living in temperate and tropical climates, whose victims are thrips, aphids, whiteflies, psilids, ticks, scale insects, larvae and eggs of Lepidoptera, and others [1]. Predatory bugs from the genus Orius (Wolff, 1811) belonging to this family have found wide application in the biological protection of various vegetable and ornamental crops from sucking pests. The Mediterranean species Orius laevigatus Fieber has been successfully tested for feeding on the whitefly Trialeurodes vaporariorum Westw. [2], the peach aphid Myzus persicae Sulz. [3], the spider mite Tetranychus urticae Koch [4]. O.

\footnotetext{
* Corresponding author: ipazyuk@gmail.com
} 
laevigatus was shown to be effective against the western flower thrips Frankliniella occidentalis Perg. [5-8]. The advantages of this species are absence of winter diapause and higher voracity than some other species $[9,10]$. The predator prefers plants inhabited by prey (thrips and spider mites) over pure plants, which indicates its ability to find prey [11]. When breeding the predator, eggs of Lepidoptera Ephestia kuehniella Zel., Sitotroga cerealella Oliv [12, 13], cysts of the crustacean Artemia sp. are used as food [14]. This species is bred on biofactories in the industrial scale of foreign and domestic firms Koppert, Biobest, Inappen [15-17] and others.

Compatibility with other biological agents of plant protection is important for the effective use of predatory bugs. Entomopathogenic fungi (EPF) from the genera Metarhizium, Beauveria, Isaria, Lecanicillium can serve as such agents. EPF from these genera are widely used in world practice as biological agents against various pests. While representatives of the genera Beauveria and Metarhizium are widespread and more studied as pathogens of beetles (Coleoptera) and butterflies (Lepidoptera), fungi of the genus Lecanicillium are natural pathogens of aphids and whiteflies and are of particular interest for the control of insects from the order Hemiptera [18-20]. The species Lecanicillium muscarium (Petch) Zare\&Gams (Ascomycota: Hypocreales) is also a promising producer of microbiological preparations for control of the tobacco whitefly [21, 22]. Numerous biological preparations have been developed abroad on the basis of fungal spores of fungi of the genus Lecanicillium [23]. Biopreparation Biovert is registered in Russia, Sibbiopharm Ltd, based on blastospores of the fungus Lecanicillium lecanii (Zimm.) Zare\&Gams. It is used for protecting cucumbers and flower crops in greenhouses from sucking pests [24].

The successful use of any biological insecticide depends not only on effectiveness against targeted prey, but also on low virulence against non-target beneficial insects [25]. Biological control programs on protected crops often recommend the use of two or more protective agents (parasitoids, predators, or pathogens) [26]. When using integrated pest management systems (IPM), it is necessary that the components of these systems are compatible [27]. Although arthropods can be carriers of fungal spores during horizontal transfer, their role in vector-host systems is not always defined [28]. An increase in the efficiency of using Neoseiulus cucumeris Oud mites (= Amblyseius cucumeris) and Amblyseius swirskii Athias-Henriot together with the fungus Beauveria bassiana Balsamo Vuill. against his victim the citrus psylide Diaphorina citri Kuw. [29], the predatory beetle Poecilus versicolor Sturm together with the fungus B. brongniartii Sacc. against the beetle Melolontha melolontha L. [25], the parasitoid Aphidius colemani Vier. together with B. bassiana and Metarhizium brunneum Petch against the peach aphid M. persicae was noted [30]. However, a decrease of efficiency at the release of the predatory mite N. barkeri Hugh together with treatment by the fungus B. bassiana was found due to the more frequent grooming of the predator [31].

Compatibility with other biological protective agents is important for the effective use of predatory bugs. The information about the effect of EPF on predatory bugs is rather scarce. In some cases, there is no negative effect of fungal spores on the number of predatory bugs $[32,33,27]$. The combined use of Metarhizium anisopliae (Metschn.) Sorokin and O. laevigatus showed a synergistic effect against the western flower thrips [34]. Field application of M. brunneum fungus against Diatraea saccharalis Fabr. did not reduce the number of live predatory bugs O. insidiosus Say [27]. The PreFeRalTM preparation based on the spores of the fungus Paecilomyces fumosoroseus (Wize) Brown, Smith (strain Apopka-97) did not cause significant mortality of the nymphs of the predators Macrolophus caliginosus Wagner, O. insidiosus, and O. laevigatus [35]. For the predatory bug $\mathrm{O}$. insidiosus, it was shown that during its release, it is important to reduce the humidity of the substrate treated with the fungus [25]. 
For O. laevigatus, its resistance to infection and the ability to transfer conidia of the entomopathogenic fungi Lecanicillium longisporum (Petch) Zare\&Gams, and L. muscarium were established for subsequent infection of the peach aphid M. persicae and the western flower thrips F. occidentalis without losing the reproductive functions of the predator. Therefore, the possibility of spreading the infection in the pest population by applying spores to the larvae of the entomophage is substantiated [36]. On the other hand, under the influence of EPF of such species as B. bassiana and M. anisopliae, a change in the behavioral reactions of predatory bugs was revealed. The predominance of the repellant effect of volatile organic compounds (VOCs) of the spores of these fungi for the predatory bug Anthocoris nemorum L. was noted [37]. Among other reactions, a decrease in predation for the bug Dicyphus hesperus Knight towards the whitefly treated with the fungus B. bassiana was noted [33].

We have previously shown that highly pathogenic strains of fungi from the genus Lecanicillium exhibited repellency against the greenhouse whitefly adults and caused a significant decrease in its fecundity [38]. A similar effect was noted for the adults of the western flower thrips [39].

The influence of spores and sporulating mycelium of the genus Lecanicillium on the behavioral responses of predatory bugs and their fecundity has not been studied, which was the purpose of this paper. The solution of this issue is of particular interest, since these biological agents are active against a complex of dangerous pests (thrips, aphids and whiteflies), and their combined use can lead to an increase in the effectiveness of biological protection.

\section{Methods}

The tests were carried out with 13 strains of entomopathogenic fungi belonging to 7 species from the genera Lecanicillium selected from the Collection of pathogenic microorganisms of the FSBSI VIZR (WFCC WDCM No. 760). Several species belonging to the genus Lecanicillium are currently assigned to the genus Akanthomyces: Akanthomyces muscarius (Petch) Spatafora, Kepler \& B. Shrestha (= L. muscarium), Akanthomyces lecanii (Zimm.) Spatafora, Kepler \& B. Shrestha (= L. lecanii) and Akanthomyces dipterigenus (Petch) Spatafora, Kepler, Zare \& B. Shrestha (= L. longisporum) and Akanthomyces pissodis Kope, Leal ( $=$ L. pissodis) [40]. Since the belonging of these species to the genus Akanthomyces remains controversial, the traditional names of species and genus are used in the references and in our paper. Strain ARSEF 8057 and strain ARSEF 2332 were obtained from the ARSEF USDA Collection (USA). Strains Vit 71 and Vit 117 were obtained from G. R. Lednev (Russia, St. Petersburg). Cultures are maintained in test tubes on Czapek's medium at $+4{ }^{\circ} \mathrm{C}$ and subcultured annually.

Sporulating mycelium was obtained after growing the strains under standard conditions on Czapek's medium in Petri dishes for 10 days. Blocks with mycelium were cut out with a microbiological punch and placed on the leaves of the common beans (Vícia fába L.) [41].

The predatory bugs $\mathrm{O}$. laevigatus were grown according to the method developed by the authors [42] in $500 \mathrm{ml}$ plastic containers; the eggs of the grain moth S. cerealella and the cereal aphid Schizaphis graminum Rond, on wheat seedlings served as food for the bugs.

The bugs $O$. laevigatus are characterized by high mobility and it needs for an area of the leaf surface sufficient for normal life. Taking this feature into account, we determined the optimal number of insects in the experiments and the processing method for studying the olfactory reactions of the bugs in response to the EPF mycelium. Plastic Petri dishes 9 $\mathrm{cm}$ in diameter were used as chambers. The bottom of the cups was lined with filter paper, which was moistened. On opposite side of the dish, two cut bean leaves were placed upside down. On each leaf the food for predatory bugs was poured - fresh eggs of grain moths (ad 
libitum). A block of sporulating fungal mycelium (experiment) was placed on one of the leaves above the food, and a block of pure agar (control) was placed on the other one. In the center of the Petri dish 3 sexually mature individuals of the bug were released (regardless of sex) with the help of an exhauster. A day later, the distribution of bugs, the number of females and the number of eggs laid by the females were recorded. The experiment was carried out in 10 replicates. Data analysis was performed using the Kruskal-Wallis nonparametric test (in the Systat 12 program).

The distribution of the bug adults was assessed using the index of aggregation (IA) (IA $=[$ (number of insects on test leaf number of insects on control leaf $) /$ (number of insects on a control leaf + number of insects on a processed leaf $) \times 100)$ [43]. It is assumed that the test substances exhibit attractiveness at IA $>0$ and repellency at IA $<0$, with statistically significant differences between the two options.

\section{Results}

When studying the influence of spores and EPF mycelium on the behavior of the bugs, the proportion of reacted individuals was high and ranged from 81 to $100 \%$. It was found that the neutral reaction prevailed in the behavior of O. laevigatus (Table 1).

Table 1. Influence of entomopathogenic fungi of the genus Lecanicillium on olfactory reactions and fecundity of bugs $\mathrm{O}$. laevigatus.

\begin{tabular}{|c|c|c|c|c|c|c|c|c|c|c|}
\hline \multirow[b]{2}{*}{$\begin{array}{c}\text { Strai } \\
\mathbf{n}\end{array}$} & \multirow[b]{2}{*}{$\begin{array}{c}\text { Speci } \\
\text { es }\end{array}$} & \multirow{2}{*}{$\begin{array}{c}\text { The } \\
\text { prop } \\
\text { ortio } \\
\text { n of } \\
\text { bugs } \\
\text { who } \\
\text { react } \\
\text { ed, } \\
\%\end{array}$} & \multicolumn{2}{|c|}{$\begin{array}{c}\text { Distribution in } \\
\text { a day, bugs/per } \\
\text { leaf }\end{array}$} & \multirow[b]{2}{*}{ IA } & \multirow[b]{2}{*}{$\mathbf{R}$} & \multirow{2}{*}{$\begin{array}{c}\mathbf{R} \\
\mathbf{e} \\
\mathbf{a} \\
\mathbf{c} \\
\mathbf{t i} \\
\mathbf{0} \\
\mathbf{n}\end{array}$} & \multicolumn{2}{|c|}{$\begin{array}{c}\text { Number of eggs } \\
\text { laid by one } \\
\text { female/per leaf }\end{array}$} & \multirow[b]{2}{*}{$\mathbf{P}$} \\
\hline & & & $\begin{array}{c}\text { Experi } \\
\text { ment }\end{array}$ & $\begin{array}{c}\text { Contr } \\
\text { ol }\end{array}$ & & & & $\begin{array}{c}\text { Experi } \\
\text { ment }\end{array}$ & $\begin{array}{c}\text { Contr } \\
\text { ol }\end{array}$ & \\
\hline V1 5 & $\begin{array}{c}\text { L. } \\
\text { lecanii }\end{array}$ & 85 & $\begin{array}{l}1.6 \pm \\
0.2 \mathrm{~A}\end{array}$ & $\begin{array}{l}0.7 \pm \\
0.2 \mathrm{~V}\end{array}$ & $\begin{array}{c}+43 . \\
3\end{array}$ & $\begin{array}{c}0.00 \\
7\end{array}$ & $\begin{array}{l}\mathrm{A} \\
*\end{array}$ & $\begin{array}{l}4.5 \pm \\
0.8 \mathrm{~A}\end{array}$ & $\begin{array}{l}4.2 \pm \\
1.4 \mathrm{~A}\end{array}$ & $\begin{array}{c}0.62 \\
3\end{array}$ \\
\hline Vl 29 & $\begin{array}{c}\mathrm{L} . \\
\text { lecanii }\end{array}$ & 87 & $\begin{array}{l}0.8 \pm \\
0.1 \mathrm{~A}\end{array}$ & $\begin{array}{l}1.8 \pm \\
0.1 \mathrm{~V}\end{array}$ & $\begin{array}{c}- \\
40.7\end{array}$ & $\begin{array}{c}0.00 \\
04\end{array}$ & $\begin{array}{l}\mathrm{R} \\
*\end{array}$ & $\begin{array}{l}2.4 \pm \\
0.5 \mathrm{~A}\end{array}$ & $\begin{array}{l}2.7 \pm \\
0.6 \mathrm{~A}\end{array}$ & $\begin{array}{c}0.90 \\
9\end{array}$ \\
\hline F2 & $\begin{array}{c}\text { L. } \\
\text { lecanii }\end{array}$ & 84 & $\begin{array}{l}1.2 \pm \\
0.3 \mathrm{~A}\end{array}$ & $\begin{array}{l}1.3 \pm \\
0.3 \mathrm{~A}\end{array}$ & -6.6 & $\begin{array}{c}0.81 \\
3\end{array}$ & $\mathrm{H}$ & $\begin{array}{l}2.4 \pm \\
0.8 \mathrm{~A}\end{array}$ & $\begin{array}{l}4.0 \pm \\
1.0 \mathrm{~A}\end{array}$ & $\begin{array}{c}0,25 \\
3\end{array}$ \\
\hline Vl 13 & $\begin{array}{c}\text { L. } \\
\text { longis } \\
\text { porum }\end{array}$ & 89 & $\begin{array}{c}1.4 \pm \\
0.2 \mathrm{~A}\end{array}$ & $\begin{array}{l}1.1 \pm \\
0.2 \mathrm{~A}\end{array}$ & $\begin{array}{c}+21 \\
1\end{array}$ & $\begin{array}{c}0.26 \\
2\end{array}$ & $\mathrm{H}$ & $\begin{array}{l}3.4 \pm \\
0.5 \mathrm{~A}\end{array}$ & $\begin{array}{l}4.1 \pm \\
0.7 \mathrm{~A}\end{array}$ & $\begin{array}{c}0.40 \\
3\end{array}$ \\
\hline V1 21 & $\begin{array}{l}\text { L.mus } \\
\text { carium }\end{array}$ & 81 & $\begin{array}{l}1.3 \pm \\
0.2 \mathrm{~A}\end{array}$ & $\begin{array}{l}1.0 \pm \\
0.2 \mathrm{~A}\end{array}$ & +6.6 & $\begin{array}{c}0.22 \\
6\end{array}$ & $\mathrm{H}$ & $\begin{array}{l}3.0 \pm \\
0.6 \mathrm{~A}\end{array}$ & $\begin{array}{l}4.4 \pm \\
0.6 \mathrm{~A}\end{array}$ & $\begin{array}{c}0.20 \\
9\end{array}$ \\
\hline Vl 61 & $\begin{array}{l}\text { L.mus } \\
\text { carium }\end{array}$ & 90 & $\begin{array}{l}1.5 \pm \\
0.3 \mathrm{~A}\end{array}$ & $\begin{array}{l}1.1 \pm \\
0.2 \mathrm{~A}\end{array}$ & $\begin{array}{c}+11 . \\
1\end{array}$ & $\begin{array}{c}0.29 \\
0\end{array}$ & $\mathrm{H}$ & $\begin{array}{l}2.6 \pm \\
0.8 \mathrm{~A}\end{array}$ & $\begin{array}{l}1.4 \pm \\
0.3 \mathrm{~A}\end{array}$ & $\begin{array}{c}0.49 \\
4\end{array}$ \\
\hline V1 72 & $\begin{array}{l}\text { L.mus } \\
\text { carium }\end{array}$ & 88 & $\begin{array}{l}1.1 \pm \\
0.2 \mathrm{~A}\end{array}$ & $\begin{array}{l}1.5 \pm \\
0.2 \mathrm{~A}\end{array}$ & $\begin{array}{c}- \\
23.3\end{array}$ & $\begin{array}{c}0.20 \\
8\end{array}$ & $\mathrm{H}$ & $\begin{array}{l}2.3 \pm \\
1.3 \mathrm{~A}\end{array}$ & $\begin{array}{l}5.1 \pm \\
0.9 \mathrm{~V}\end{array}$ & $\begin{array}{c}0.01 \\
3 *\end{array}$ \\
\hline
\end{tabular}




\begin{tabular}{|c|c|c|c|c|c|c|c|c|c|c|}
\hline \multirow{2}{*}{$\begin{array}{c}\begin{array}{c}\text { Strai } \\
\mathbf{n}\end{array} \\
\mathrm{V} 178\end{array}$} & \multirow{2}{*}{$\begin{array}{c}\begin{array}{c}\text { Speci } \\
\text { es }\end{array} \\
\begin{array}{c}\text { L. } \\
\text { psallio } \\
\text { tae }\end{array}\end{array}$} & \multirow{2}{*}{$\begin{array}{c}\begin{array}{c}\text { The } \\
\text { prop } \\
\text { ortio }\end{array} \\
96\end{array}$} & \multicolumn{2}{|c|}{$\begin{array}{c}\text { Distribution in } \\
\text { a day, bugs/per } \\
\text { leaf }\end{array}$} & \multirow{2}{*}{$\begin{array}{c}\text { IA } \\
-3.3\end{array}$} & \multirow{2}{*}{$\begin{array}{c}\mathbf{R} \\
0.38 \\
4\end{array}$} & \multirow{2}{*}{$\begin{array}{l}\mathbf{R} \\
\mathbf{e} \\
\mathbf{a} \\
\mathrm{H}\end{array}$} & \multicolumn{2}{|c|}{$\begin{array}{l}\text { Number of eggs } \\
\text { laid by one } \\
\text { female/per leaf }\end{array}$} & \multirow{2}{*}{$\begin{array}{c}\mathbf{P} \\
0.30 \\
6\end{array}$} \\
\hline & & & $\begin{array}{l}1.2 \pm \\
0.2 \mathrm{~A}\end{array}$ & $\begin{array}{l}1.5 \pm \\
0.3 \mathrm{~A}\end{array}$ & & & & $\begin{array}{r}4.7 \pm \\
0.8 \mathrm{~A}\end{array}$ & $\begin{array}{l}3.6 \pm \\
0.8 \mathrm{~A}\end{array}$ & \\
\hline V1 79 & $\begin{array}{c}\text { L. } \\
\text { dimor } \\
\text { phum }\end{array}$ & 100 & $\begin{array}{l}1.0 \pm \\
0.3 \mathrm{~A}\end{array}$ & $\begin{array}{l}1.8 \pm \\
0.3 \mathrm{~A}\end{array}$ & $\begin{array}{c}- \\
33.3\end{array}$ & $\begin{array}{c}0.45 \\
4\end{array}$ & $\mathrm{H}$ & $\begin{array}{l}1.5 \pm \\
0.6 \mathrm{~A}\end{array}$ & $\begin{array}{l}2.8 \pm \\
0.8 \mathrm{~V}\end{array}$ & $\begin{array}{c}0.01 \\
7^{*}\end{array}$ \\
\hline $\begin{array}{c}\text { ARS } \\
\text { EF23 } \\
32\end{array}$ & $\begin{array}{c}\text { L. } \\
\text { dimor } \\
\text { phum }\end{array}$ & 83 & $\begin{array}{l}0.7 \pm \\
0.2 \mathrm{~A}\end{array}$ & $\begin{array}{l}1.7 \pm \\
0.2 \mathrm{~V}\end{array}$ & $\begin{array}{c}- \\
50.0\end{array}$ & $\begin{array}{c}0.00 \\
3\end{array}$ & $\begin{array}{l}\mathrm{R} \\
*\end{array}$ & $\begin{array}{l}2.2 \pm \\
0.6 \mathrm{~A}\end{array}$ & $\begin{array}{l}3.9 \pm \\
0.7 \mathrm{~A}\end{array}$ & $\begin{array}{c}0.07 \\
5\end{array}$ \\
\hline $\begin{array}{c}\text { ARS } \\
\text { EF } \\
8057\end{array}$ & $\begin{array}{c}\text { L. } \\
\text { pissodi } \\
\mathrm{s}\end{array}$ & 97 & $\begin{array}{c}1.0 \pm \\
0.2 \mathrm{~A}\end{array}$ & $\begin{array}{l}1.9 \pm \\
0.2 \mathrm{~A}\end{array}$ & 23.3 & $\begin{array}{c}0.19 \\
4\end{array}$ & $\mathrm{H}$ & $\begin{array}{l}3.3 \pm \\
1.1 \mathrm{~A}\end{array}$ & $\begin{array}{l}4.2 \pm \\
0.9 \mathrm{~A}\end{array}$ & $\begin{array}{c}0.62 \\
8\end{array}$ \\
\hline Vit 71 & $\begin{array}{c}\text { L. } \\
\text { attenu } \\
\text { atum }\end{array}$ & 85 & $\begin{array}{l}0.7 \pm \\
0.2 \mathrm{~A}\end{array}$ & $\begin{array}{l}1.5 \pm \\
0.2 \mathrm{~V}\end{array}$ & - & $\begin{array}{c}0.02 \\
2\end{array}$ & $\begin{array}{l}\mathrm{R} \\
*\end{array}$ & $\begin{array}{l}2.5 \pm \\
0.7 \mathrm{~A}\end{array}$ & $\begin{array}{l}2.0 \pm \\
0.4 \mathrm{~A}\end{array}$ & $\begin{array}{c}0.51 \\
9\end{array}$ \\
\hline $\begin{array}{l}\text { Vit } \\
117\end{array}$ & $\begin{array}{c}\text { L. } \\
\text { attenu } \\
\text { atum }\end{array}$ & 93 & $\begin{array}{l}1.1 \pm \\
0.3 \mathrm{~A}\end{array}$ & $\begin{array}{l}1.5 \pm \\
0.3 \mathrm{~A}\end{array}$ & $\begin{array}{c}- \\
16.6\end{array}$ & $\begin{array}{c}0.23 \\
6\end{array}$ & $\mathrm{H}$ & $\begin{array}{l}1.7 \pm \\
0.5 \mathrm{~A}\end{array}$ & $\begin{array}{l}3.4 \pm \\
0.8 \mathrm{~A}\end{array}$ & $\begin{array}{c}0.10 \\
4\end{array}$ \\
\hline
\end{tabular}

Note: options are marked with the same letters, where the difference between the experiment and the control is not significant, different letters and * indicate options that significantly differ from the control at $\mathrm{P} \leq 0.05$ (according to Kruskal-Wallis)

Sporulating mycelium of three strains: V1 29 (L. lecanii), ARSEF 2332 (L. dimorphum), Vit 71 (L. attenuatum) $(\mathrm{P}<0.05)$ caused a significant repellent reaction on the bugs. The index of aggregation ranged from -40.7 to -50 . Three strains of the species L. lecanii led to different reactions: strain Vl 5 caused a strong attractive reaction in predators $(\mathrm{P}<0.05)$ (IA $=+43.3)$, V1 $29-$ a strong repellent reaction $(\mathrm{P}<0.05)(\mathrm{IA}=-40.7)$, and $\mathrm{F} 2-$ to a neutral reaction $(\mathrm{P}>0.05)$. The influence of three strains of the species L. muscarium (Vl 21, Vl 61, V1 72) in relation to bugs was insignificant, neutral reactions with different tendencies were observed. The V1 13 strain of the L. longisporum species also caused a tendency towards attractiveness for bugs.

The rest of the strains showed a neutral reaction for the bug adults or showed a tendency towards repellency: after 24 hours, the number of bugs on the experimental and control leaves did not differ significantly.

When testing strains V1 72 and Vl 79, females laid significantly more eggs on the control leaf (with agar) than on the test leaf (with mycelium block), despite the fact that the reaction of bugs to the mycelium of the fungus was neutral. Wherein, the strains showing the repellant reaction of bugs (V1 29, ARSEF 2332 and Vit 71) did not affect the fecundity of females, the number of eggs in the experiment and in the control was similar.

\section{Discussion}

According to the published data, EPF of the order Hypocreales cause predominantly repellent effect on insects [44]. This was also shown for bug species related to O. laevigatus 
from the family Anthocoridae - the predatory bug A. nemorum in response to volatile compounds of spores of the fungi B. bassiana and M. anisopliae [37].

According to our results, the reactions of bugs in response to EPF mycelium were different. Moreover, strains of one species L. lecanii caused opposite behavioral reactions of the bugsorius. Similar intraspecific differences in the level of VOC formation were found in two strains of B. bassiana, which also differed in the level of repellency towards termites [45]. The attractiveness of EPF for hosts or predators is much less common than repellency. Fungi Beauveria bronginiartii and $M$. anisopliae were attractive for collembolans [46], certain species of fungi of the genus Fusarium were attractive for rice weevil beetles [47]. The attractiveness of L. lecanii strain Vl 5 for O. laevigatus requires further study; it may be related to the peculiarities of the VOC composition of the mycelium of this strain.

As a result of the experiments, no relationship was found between the repellency of strains and a decrease in fecundity of bug female. It can be assumed that the negative influence of the mycelium of individual EPF strains on the fecundity of the predator is of more important (specific) significance, which determines the success of hatching and feeding of offspring in the future, than the location of the bug. The decrease in fecundity may depend on the VOC composition of the mycelium of individual strains. On the other hand, strains showing a repellant response to the bugs but not affecting female fecundity probably do not pose a serious threat to O.laevigatus.

\section{Conclusion}

When studying the influence of spores and mycelium of entomopathogenic fungi of the genus Lecanicillium on the behavior of predatory bug O. laevigatus, it was shown that in most cases the reaction of bugs to fungi is neutral. However, the manifestation of repellent or attractive reactions of a predator to certain strains is possible.

In the presence of mycelium of two strains, a decrease in the daily fecundity of bugs was noted. The data obtained must be taken into account when developing a strategy for the combined use of predatory bugs and entomopathogenic fungi.

The authors are grateful to Stepanycheva E. A. for advice on research methods and Binitskaya N.V. for help with the experiment.

This paper was supported by the Russian Foundation for Basic Research (Grant No. 20-016-00241).

\section{References}

1. F.V. Dunkel, S.T. Jaronski, J. Econ. Entomol., 96, 4 (2003)

2. E.P. Mokrousova, Bulletin of Plant Protection, 76, 1 (2001)

3. I.M. Pazyuk, N.V. Binitskaya, Pl. Prot. News, 103, 4 (2020)

4. M. Venzon, A. Janssen, M. W. Sabelis, OIKOS, 97 (2002)

5. R.J. Chambers, S. Long, N.L. Helyer, Bioc. Sci. and Tech., 3, 3 (1993)

6. M.G. Tommasini, S. Maini, In: Thrips and Tospovirus: Proceedings of the International Symposium on Thysanoptera (2002)

7. A.A. Saprykin, I. M. Pazyuk, Gavrish, 3 (2003)

8. O.V. Ermakova (Trapeznikova), E.A. Varfolomeeva, Inf. Bull. VPRS MOBB, 42 (2011)

9. G.E. Cocuzza, P. De Clercq, S. Lizzio, M. Van de Veire, L. Tirry, D. Degheele, V. Vacante, Ent. Exp. et Appl., 85 (1997)

10. M. G. Tommasini, J. C. van Lenteren, Bull. of Ins., 56, 2 (2003)

11. M. Venzon, A. Janssen, M. W. Sabelis, Ent. Exp. et Appl., 93 (1999) 
12. G.E. Cocuzza, P. De Clercq, M. Van de Veire, A. De Cock, D. Degheele, V. Vacante, Entomol. Exp. Appl., 82 (1997)

13. M.K. Mironova, S.S. Izhevsky, A.K. Akhatov, Sat. scientific. tr. "Problems of entomology in Russia" (St. Petersburg, 1998)

14. Y. Arijs, P. De Clercq, Biol. Cont., 21 (2001)

15. Koppert biological systems (Koppert Biological Systems, 2020)

16. Biobest sustainable crop management (Biobest Group NV, 2020)

17. Research and Production Enterprise. Institute of Applied Entomology (Research and Production Enterprise «Institute of Applied Entomology», 2020)

18. R.A. Hall, Academic Press (London, 1981)

19. M.S. Goettel, M. Koike, J.J. Kim, D. Aiuchi, J. of Inv. Path., 98 (2008)

20. H. Askary, H. Yarmand, Eur. J. Entomol., 104 (2007)

21. A.S. Cuthbertson, L. Blackburn, P. Northing, W. Luo, J.C. Raymond, K.F. Cannon, A. Walterset, Ins. Sci., 15, 4 (2008)

22. S. Ali, C. Zhang, Z. Wang, X.M. Wang, J.H. Wu, A.G.S. Cuthbertson, Z. Shao, B.L. Qiu, Sci. Rep., 7 (2017)

23. M.R. De Faria, S.P. Wraight, Biol. Cont., 43, 3 (2007)

24. State catalog of pesticides and agrochemicals permitted for use on the territory of the Russian Federation (approved by the Ministry of Agriculture of Russia) (2020)

25. Y. Gao, S. R. Reitz, J. Wang, P. Tamez-Guerra, E. Wang, X. Xu, Z. Lei, Bio. Sci. and Tech., 22, 7 (2012)

A. Chow, A. Chau, K. M. Heinz, Biol. Cont., 44 (2008)

26. O.E. Rosales-Escobar, A.P. Terán-Vargas, L. Guizar-Guzmán, A. Azuara-Domínguez, S.R. Sánchez-Peña, South. Ent., 41, 1 (2016)

27. G. Lin, A. Tanguay, C. Guertin, S. Todorova, J. Brodeur, Biol. Cont., 115 (2017)

28. Y.-X. Zhang, L. Sun, G.-Y. Lin, J.-Z. Lin, X. Chen, J. Ji, Z. Zhang, Y. Saito, Sys. and App. Acar., 20, 2 (2015)

29. L.R. Jaber, S.-E. Araj, Biol. Cont., 116 (2018)

30. S. Wu, Y. Gao, G. Smagghe, X. Xu, Z. Lei, Biol. Cont., 98 (2016)

31. C.R. Alma, M.S. Goettel, B.D. Roitberg, D.R. Gillespie, BioC., 52 (2007)

32. R.M. Labbé, D.R. Gillespie, C. Cloutier, J. Brodeur, Bioc. Sci. and Tech., 19, 4 (2009)

33. J. A. Otieno, P. Pallmann, H.-M. Poehling, BioC., 62 (2017)

34. C.R. Alma, M.S. Goettel, B. D. Roitberg, D. R. Gillespie, BioC., 52 (2007)

35. R.E. Down, A.G.S. Cuthbertson, J.J. Mathers, K. F.A. Walters, Biol.l Cont., 50 (2009)

36. N.V. Meyling, J.K. Pell, Ecol. Ent., 31, 2 (2006)

37. G.V. Mitina, E.A. Stepanycheva, A.A. Choglokova, Bulletin of plant protection, 103, 4 (2020)

38. G.V. Mitina, E.A. Stepanycheva, M.O. Petrova, Parasitology, 53, 3 (2019)

39. R.M. Kepler, J.J. Luangsa-Ard, N.L. Hywel-Jones, C.A. Quandt, et al., IMA Fung., 8, 2 (2017)

40. G.V. Mitina, O. G. Selitskaya, A.V. Shchenikova, Entomological Review, 99, 2 (2020)

41. I.M. Pazyuk, A.L. Vasiliev, Bulletin of plant protection, 92, 2 (2017)

42. M.J. Pascual-Villalobos, A. Robledo, Ind. Crops Prod., 8 (1998)

43. H.E. Roy, D.C. Steinkraus, J. Eilenberg, A.E. Hajek, J.K. Pell, Ann. Rev. of Ent., 51 (2006)

44. D.M. Mburu, N.K. Maniania, A. Hassanali, J. of Chem. Ec., 39 (2013)

45. K.M. Dromph, S. Vestergaard, Appl. Soil Ec., 21, 3 (2002)

46. O.G. Selitskaya, O.P. Gavrilova, A.V. Schenikova, I.V. Shamshev, T.Y. Gagkaeva, Ent. Rev., 94 (2014) 